\title{
Analisis Nilai Impedansi Listrik pada Daging Ikan Nila yang Disimpan dalam Lemari Es
}

\author{
Rizka Rahmatie A.P. ${ }^{*}$ Chomsin Sulistya $^{2}$, dan Didik R. Santoso ${ }^{2}$ \\ ${ }^{1}$ Program Studi Magister Ilmu Fisika, Jurusan Fisika, Universitas Brawijaya \\ ${ }^{2}$ Jurusan Fisika, Fakultas MIPA, Universitas Brawijaya \\ 1*Email: rizkaka.gege16@gmail.com
}

DOI: http://dx.doi.org/10.13057/ijap.v6i02.1780

\begin{abstract}
Electrical impedance value analysis on frozen tilapia flesh aims to analyze non-destructive method of electrical impedance to distinguish between fresh and frozen tilapia flesh. The measurements were carried out to measure electrical impedance fresh tilapia flesh and frozen tilapia flesh for 1-5 days at $10 \mathrm{~Hz}-200 \mathrm{kHz}$ frequency using needle electrode. The result shows that the impedance value characteristics of the fresh tilapia flesh is higher than frozen tilapia flesh. The longer strored in the freezer is directly reversed with the value of electrical impedance. The observation of electrical impedance on quality of tilapia flesh preferable observed at a frequency of $1 \mathrm{kHz}-100 \mathrm{kHz}$.
\end{abstract}

Keywords: tilapia flesh, frozen, frequency, electrical impedance

\section{ABSTRAK}

Analisis nilai impedansi listrik pada daging ikan nila yang disimpan dalam lemari es bertujuan untuk menganalisis metode impedansi yang bersifat non destruktif yang dapat digunakan untuk membedakan daging ikan segar dan daging ikan dalam lemari es. Pengukuran yang dilakukan yaitu mengukur nilai impedansi daging ikan nila segar dan daging ikan nila yang telah disimpan dalam lemari es selama 1-5 hari pada frekuensi $10 \mathrm{~Hz}$ - $200 \mathrm{kHz}$ dengan menggunakan elektroda jarum. Hasil penelitian menampilkan karakteristik nilai impedansi daging ikan nila segar memiliki nilai impedansi lebih tinggi daripada daging ikan nila yang sudah disimpan dalam lemari es. Lama waktu penyimpanan dalam lemari es memiliki hubungan berbanding terbalik dengan nilai impedansi. Pengamatan nilai impedansi listrik terhadap mutu daging ikan nila sebaiknya diamati pada frekuensi 1 $\mathrm{kHz}-100 \mathrm{kHz}$.

Kata kunci : daging ikan nila, formalin, frekuensi, impedansi listrik

\section{PENDAHULUAN}

Ikan adalah sumber makanan yang kaya akan protein, lemak, vitamin (A dan D), dan mikroelemen lainnya. Ikan yang dibiarkan saja tanpa diberi perlakuan pengawetan akan mudah membusuk. Pedagang ikan selalu menggunakan cara pengawetan untuk menjaga ikan agar tetap segar. Metode pengawetan yang sering dilakukan oleh para pedagang adalah menyimpan ikan dalam lemari es.

Penentuan tingkat kesegaran ikan dan kualitas daging ikan dilakukan secara objektif melalui analisis perubahan sifat kimia, komponen degradasi ATP, kandungan biogenik, komponen volatil, atau analisis kandungan mikrobiologi (Riyanto et al. 2012). Metode ini kurang efisien dan prakteknya sangat rumit.

Impedansi listrik merupakan salah satu besaran kelistrikan yang dapat digunakan untuk mengetahui karakteristik biolistrik pada bahan biologis. Karakteristik biolistrik ini dapat 
dikorelasikan pada kondisi jaringan, sifat-sifat fisika-kimia jaringan, dan dianalisis kandungan apa saja yang terdapat pada jaringan, sehingga sifat biolistrik tersebut dapat digunakan untuk menilai kemurnian dan kualitas suatu bahan ataupun kerusakan pada jaringan. Metode impedansi telah dikembangkan pada berbagai penelitian untuk menentukan kondisi bahan pangan ${ }^{(1)}$, kadar gula darah dalam tubuh ${ }^{(2)}$, distribusi volume air dalam tubuh ${ }^{(3)}$, serta dikembangkan untuk impedansi tomografi ${ }^{(4)}$. Penggunaan nilai impedansi listrik diharapkan dapat menjadi teknik baru yang lebih mudah dan non invasif untuk menentukan kondisi bahan pangan yang meliputi bahan pangan dalam keadaan segar, busuk, maupun tercampur bahan kimia.

Tulisan ini akan memaparkan pengaruh lama penyimpanan dalam lemari es terhadap nilai impedansi daging ikan nila pada frekuensi $10 \mathrm{~Hz}-200 \mathrm{kHz}$. Penelitian ini bertujuan sebagai studi untuk membedakan daging ikan nila segar dan daging ikan nila yang telah disimpan dalam lemari es berdasarkan nilai impedansi listrik.

\section{METODE}

Sampel pada penelitian ini adalah daging ikan nila dengan ukuran yang sudah siap untuk dikonsumsi yaitu memiliki berat kurang lebih 250 gram dan berumur 4-6 bulan. Daging ikan nila disimpan dalam lemari es selama 1 hari, 2 hri, 3 hari, 4 hari, dan 5 hari.

Alat utama yang digunakan adalah pembangkit tegangan AC dua kanal yaitu Picoscope (S5000). Penggunaan Picoscope S5000 dikendalikan oleh software yang telah diinstall pada PC. Software tersebut menampilkan amplitudo dari gelombang sinusoidal tegangan pada masing-masing frekuensi tertentu.

Diagram bok sistem pengukuran ditampilkan dalam Gambar 1. Secara garis besar prinsip kerja dari sistem pengukuran adalah generator tegangan yang ada pada Picoscope diatur untuk menghasilkan tegangan sebesar 1 volt dengan frekuensi yang dapat dipilih pada jangkauan frekuensi $10 \mathrm{~Hz}-100 \mathrm{kHz}$. Rangkaian V-I Converter mengkonversi tegangan ke arus pada frekuensi yang bersesuaian, di mana nilai arus dapat dipilih sesuai dengan keperluan. Arus ini selanjutnya diinjeksikan ke probe yang digunakan. Keluaran tegangan dari probe selanjutnya dikuatkan oleh penguat instrumentasi untuk direkam oleh Picospoce Ch-2. Sinyal tegangan dari Picoscope direkam pada Ch-1 sebagai referensi pada saat yang bersamaan.

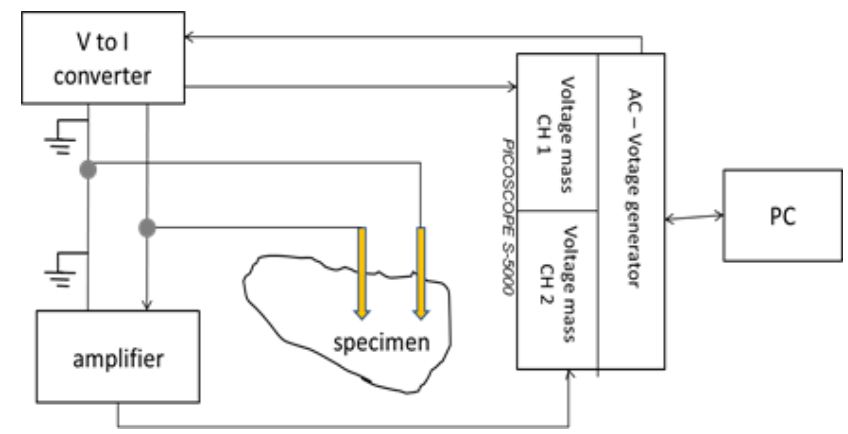

Gambar 1. (Colour Online) Blok diagram sistem pengukuran.

Probe yang digunakan dalam penelitian ini adalah elektroda jarum yang terbuat dari emas dengan ukuran diameter 0,6 $\mathrm{mm}$ dan panjang $45 \mathrm{~mm}$. Jarum elektroda akan ditusukkan pada sampel yang sudah dipersiapkan dengan kedalaman $1 \mathrm{~cm}$ seperti pada Gambar 2. 
Probe yang digunakan dalam penelitian ini adalah elektroda jarum yang terbuat dari emas dengan ukuran diameter 0,6 $\mathrm{mm}$ dan panjang $45 \mathrm{~mm}$. Jarum elektroda akan ditusukkan pada sampel yang sudah dipersiapkan dengan kedalaman $1 \mathrm{~cm}$ seperti pada Gambar 2.

Gambar 2. (Colour Online) Elektroda jarum untuk pengukuran.

Data yang didapatkan berupa nilai tegangan. Nilai tegangan ini ditampilkan oleh software yang sudah terinstal dalam PC. Gelombang sinusoidal akan tampil pada layar PC seperti terlihat dalam Gambar 3. Arus listrik yang digunakan adalah $1 \mathrm{~mA}$. Gelombang warna merah merupakan gelombang dari tegangan yang terukur pada sampel, sedangkan gelombang warna biru merupakan gelombang dari tegangan sumber yang digunakan sebagai referensi.

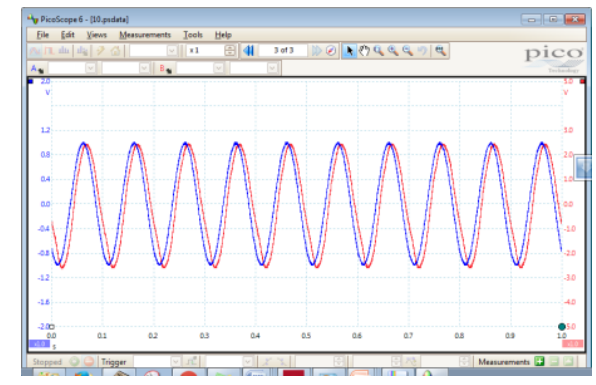

Gambar 3. (Colour Online) Tampilan gelombang tegangan.

Pengambilan data dilakukan dengan pencatatan amplitudo dari gelombang tersebut pada tiap frekuensi, sehingga data yang diperoleh berupa besarnya potensial yang terukur dalam daging ikan pada masing-masing frekuensi yang diberikan. Nilai impedansi pada tiap frekuensi diperoleh dari perbandingan nilai potensial yang terukur dan nilai arus yang diinjeksikan. Secara matematik dituliskan sebagai

$$
|Z|=\frac{V}{I}
$$

di mana $\mathrm{Z}$ adalah impedansi, $\mathrm{V}$ adalah amplitudo gelombang dari tegangan yang terukur dan I adalah arus listrik yang diinjeksikan secara konstan.

\section{HASIL DAN PEMBAHASAN}

Hasil analisis data menghasilkan grafik hubungan antara nilai impedansi dan frekuensi. Pengaruh penyimpanan pada lemari es terhadap nilai impedansi daging ikan nila menampilkan nilai impedansi yang lebih kecil daripada ikan segar. 


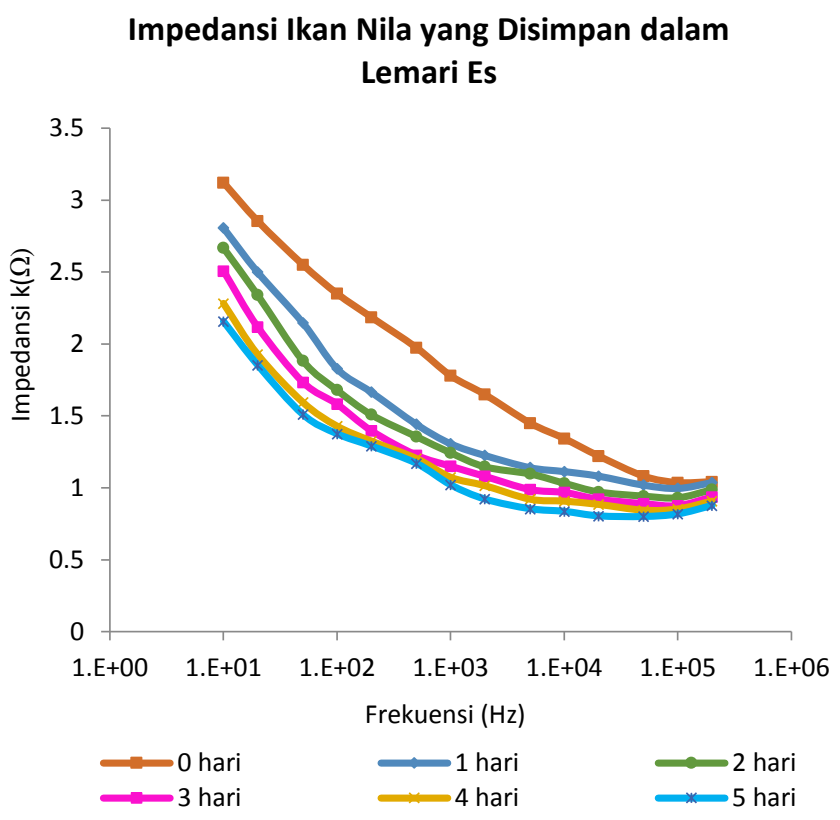

Gambar 4 (Colour Online) Hubungan frekuensi dengan nilai impedansi pada daging ikan nila yang disimpan dalam lemari es.

Perubahan nilai impedansi saat frekuensi diperbesar disebabkan karena adanya membrane sel yang bersifat seperti kapasitor. Membran sel tersebut tersebar dalam jaringan biologis. Membran sel tersusun atas molekul-molekul lipida berlapis ganda (bilayer lipids) dan terdiri atas komponen hidrofobik dan hidrofilik. Membran sel berfungsi sebagai pembatas antara cairan di luar sel dan cairan di dalam sel yang terdiri atas ion-ion garam dan bersifat konduktor. Peran membran sel sebagai batas antara dua bahan konduktor menyebabkan membran sel bersifat seperti kapasitor. Kapasitor terdiri atas dua plat konduktor yang dipisahkan dengan bahan dielektrik atau ruang hampa udara. Ilustrasi jaringan dan membran sel bersifat seperti kapasitor ditampilkan dalam Gambar 5.

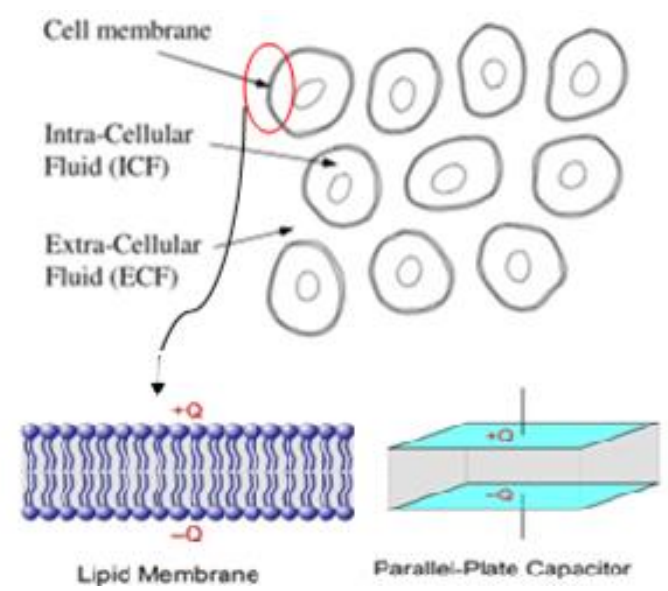

Gambar 5. (Colour Online) Ilustrasi membran sel yang bersifat seperti kapasitor (6). 


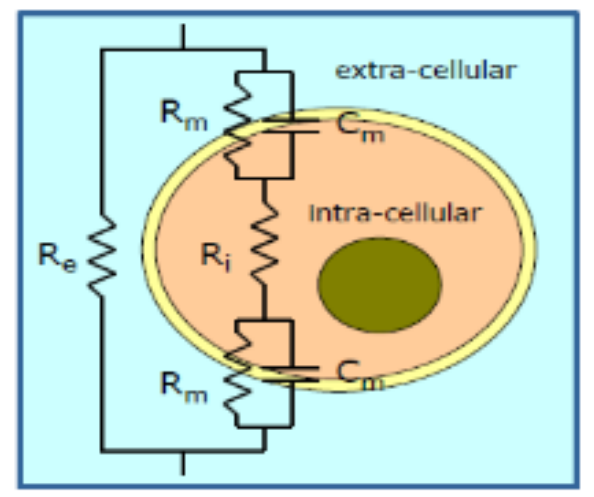

Gambar 6. (Colour Online) Rangkaian ekivalen dengan sel (7).

Jaringan tersusun atas sel yang dikelilingi membrane sel yang memiliki konduktansi dan sifat dielektrik yang berbeda. Membran sel yang bersifat seperti kapasitor bila dianalogikan seperti rangkaian listrik memiliki komponen $\mathrm{R}$ dan $\mathrm{C}$. $\mathrm{Cm}$ adalah kapasitansi membran lapisan ganda, $R i$ adalah resistansi di dalam sel, dan $R e$ adalah resistansi di luar sel, dan $R m$ adalah resistansi membran (Yang et al. 2013). Nilai $C m, R i, R e$, dan $R m$ merupakan karakteristik dari suatu jaringan terkait dengan adanya sifat membran sel, serta banyaknya ion yang terkandung dalam jaringan tersebut. Adanya indikator-indikator tersebut menyebabkan nilai impedansi pada tiaptiap jaringan dan jaringan yang telah rusak berbeda.

Model Maxwell-Wagner merupakan model untuk impedansi pada jaringan biologis. MaxwellWagner dengan menggunakan kombinasi $\mathrm{R}$ dan $\mathrm{C}$ parallel seperti pada pada rangkaian ekivalen untuk membrane sel pada Gambar 5.
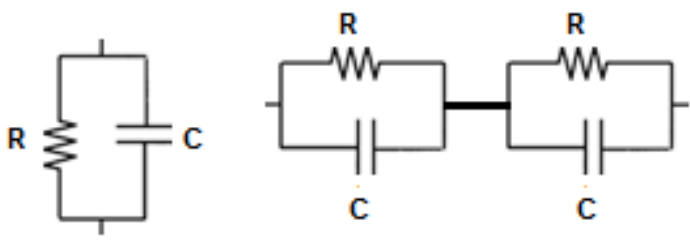

Perhitungan impedansi yang ditampilkan pada Gambar 6 adalah

$$
\frac{1}{Z(\omega)}=\frac{1}{\mathrm{R}}+j \omega C \text { atau } Z(\omega)=\frac{1}{G+j \omega C}
$$

di mana $G=\frac{1}{R}$

Kombinasi impedansi jika memiliki dua elemen Maxwell-Wagner yang disusun seri seperti pada Gambar 7 menjadi

$$
Z(\omega)=\frac{1}{G+j \omega C}+\frac{1}{G+j \omega C}
$$

Sehingga impedansi pada k membran sel yang masing-masing memiliki konduktansi $G_{l}, G_{2}$, $\ldots G_{k}$ dan kapasitansi $C_{1}, C_{2}, \ldots . C_{k}$ adalah

$$
Z(\omega)=\sum_{i=1}^{k} \frac{1}{G_{i}+j \omega C_{i}}=\frac{1}{G+j \omega C}
$$

di mana $\mathrm{G}$ adalah konduktansi total dan $\mathrm{C}$ adalah kapasitansi total pada frekuensi $\omega$. Adanya fungsi frekuensi pada nilai impedansi ini menyebabkan kurva impedansi pada Gambar 4 mengalami penurunan terhadap frekuensi. Persamaan (3) menampilkan bahwa nilai impedansi 
menjadi $1 / G$ atau $R$ jika diberikan $\omega=0$, sedangkan jika diberikan $\omega=\sim$, nilai impedansi menjadi minimum.

Pengaruh penyimpanan dalam lemari es terhadap nilai impedansi daging ikan nila dapat teramati secara lebih jelas pada frekuensi lebih dari $1 \mathrm{kHz}$ sehingga dilakukan perbesaran resolusi yang ditampilkan pada Gambar 8. Nilai impedansi pada frekuensi kurang dari $1 \mathrm{kHz}$ menampilkan kurva yang tidak stabil pada pemberian variasi lama penyimpanan yang berbeda, sehingga penelitian ini lebih difokuskan pada jangkauan frekuensi tersebut. Nilai impedansi yang paling kecil didapatkan pada daging ikan yang yang disimpan selama 5 hari.

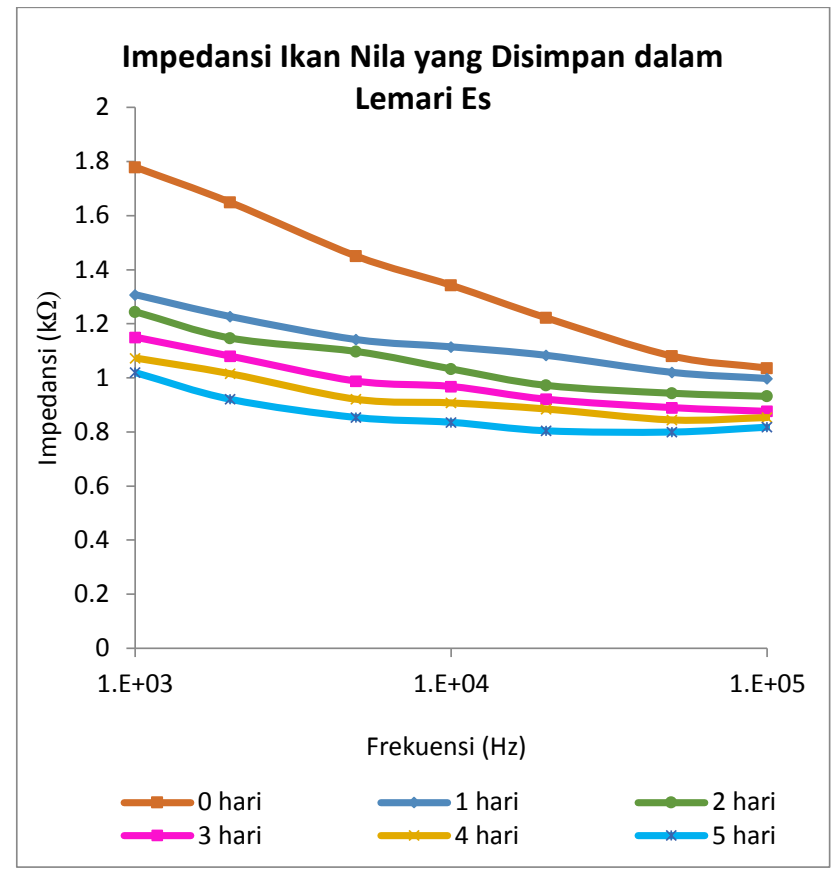

Gambar 7. (Colour Online) Hubungan frekuensi $1 \mathrm{kHz}-100 \mathrm{kHz}$ dengan nilai impedansi ikan nila penyimpanan dalam lemari es.

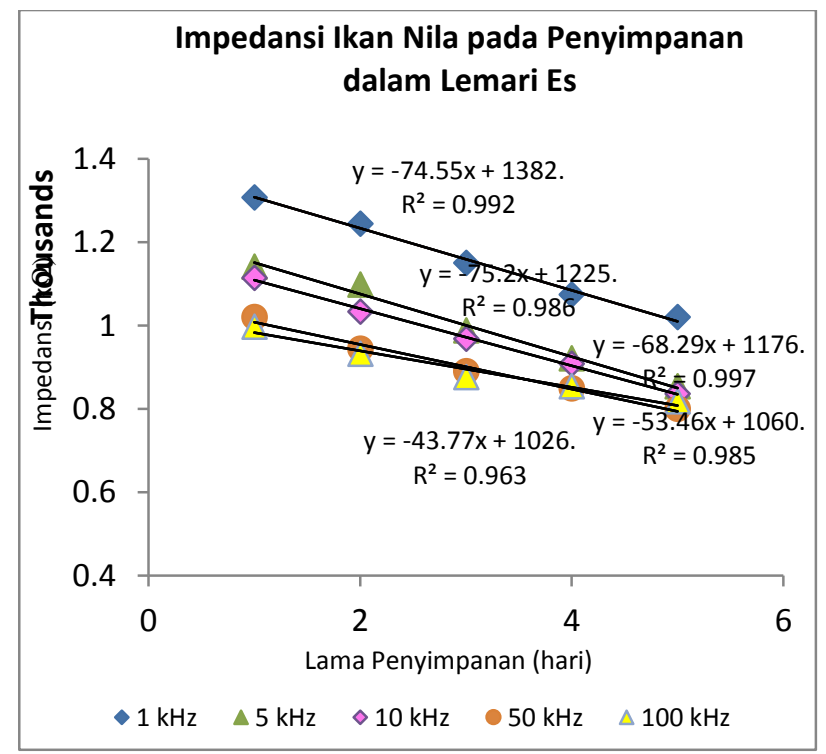

Gambar 8. (Colour Online) Hubungan lama penyimpanan dalam lemari es dengan nilai impedansi ikan nila berformalin pada frekuensi $1 \mathrm{kHz}-100 \mathrm{kHz}$. 
Gambar 9 ditampilkan untuk mengetahui respon frekuensi yang tepat untuk meneliti pengaruh penyimpanan dalam lemari es pada daging ikan nila. Hasil grafik pada Gambar.9 menampilkan hubungan yang linier antara nilai impedansi dan lama penyimpanan dalam lemari es. Kurva yang terbentuk adalah linier negatif. Semakin besar kemiringan suatu grafik mengindikasikan semakin besar pula pengaruh perlakuan terhadap nilai yang diukur. Frekuensi $10 \mathrm{kHz}$ dan 1 $\mathrm{kHz}$ memiliki nilai $\mathrm{R}^{2}$ yang besar dan nilai gradien yang besar., sehingga frekuensi $1 \mathrm{kHz}$ dan $10 \mathrm{kHz}$ direkomendasikan untuk meneliti pengaruh formalin pada ikan nila. Frekuesi $50 \mathrm{kHz}$ dan frekuensi $100 \mathrm{kHz}$ tidak direkomendasikan dalam penelitian karena hasil linerisasi kurva memiliki nilai $\mathrm{R}^{2}$ yang kecil dan memiliki gradien yang kecil. Hasil impedansi yang terukur pada frekuensi tersebut memiliki nilai yang hampir sama pada konsentrasi formalin yang berbeda, sehingga tidak dapat diketahui pengaruh adanya perbedaan konsentrasi terhadap nilai impedansi.

Hasil penelitian menampilkan semakin lama ikan disimpan dalam lemari es maka menghasilkan nilai impedansi yang semakin kecil. Penyimpanan dalam lemari es dapat mempengaruhi kemunduran mutu daging ikan. Penurunan kualitas ikan dan daging dihubungkan dengan fungsional protein dalam daging ikan tersebut yang hilang. Pengaruh tersebut disebabkan oleh saat air menjadi es, konsentrasi enzim meningkat dan membentuk konsentrasi garam pada air yang tersisa. Konsentrasi garam meningkat menyebabkan denaturasi protein dan meningkatkan konsentrasi ion metabolit. Ion $\mathrm{Na}+\mathrm{K}+$, dan $\mathrm{Cl}-$ terus menerus lepas sehingga timbul kerusakan pada sel terutama pecahnya dekomposisi protein (Hadiyanto). Peningkatan konsentrasi metabolit ion terlarut pada daging ikan menyebabkan peningkatan nilai konduktivitas listrik yang akan menghasilkan nilai impedansi yang lebih rendah.

Jumlah bakteri dan nilai impedansi memiliki hubungan linier. Semakin banyak jumlah bakteri maka nilai impedansinya semakin kecil (Solechah 2015). Gambar 10 menampilkan hubungan yang linier antara lama penyimpanan daging ikan nila dan nilai impedansi. Semakin lama penyimpanan maka semakin meningkatkan jumlah bakteri pembusuk. Pertumbuhan bakteri dan fungi pada lemari es semakin meningkat selama proses penyimpanan yang teah dibuktikan dalam penelitian tentang jumlah bakteri selama proses pendinginan bahan pangan (Siburian et al. 2012). Keberadaan bakteri pada penelitian tersebut bergantung pada lamanya proses pendinginan. Semakin lama pendinginan, bakteri yang tumbuh akan semakin banyak. Jumlah bakteri akan menurunkan nilai impedansi. Semakin lama penyimpanan dalam lemari es akan menyebabkan penurunan nilai impedansi.

Kandungan air dalam daging merupakan bagian yang mendominasi, misalnya kandungan air dalam daging sapi dan daging ayam adalah 65\% - 80\% (Fauziah 2015). Kadar air meningkat dari 68\% menjadi 69\% selama penyimpanan 4 hari (Sulastri 2006). Air merupakan konduktor di mana mempengaruhi nilai impedansi. Semakin banyak kandungan air maka mengakibatkan semakin rendah nilai impedansinya. Kondisi lingkungan saat pengukuran juga mempengaruhi hasil pengukuran seperti suhu udara dan kelembapan udara di ruangan. Kondisi fisik, kondisi lingkungan, serta perubahan frekuensi yang diberikan sangat mempengaruhi dalam pengukuran sehingga hasil yang diperoleh berbeda-beda (Fauziah 2015).

\section{KESIMPULAN}

Hasil pengukuran karakteristik biolistrik berdasar nilai impedansi pada daging ikan didapatkan kesimpulan bahwa nilai impedansi daging ikan nila segar menurun seiring dengan bertambahnya frekuensi. Perlakuan pengawetan daging ikan nila melalui penyimpanan dalam lemari es mempengaruhi nilai impedansi. Semakin lama daging ikan nila disimpan dalam 
lemari es, menghasilkan nilai impedansi semakin rendah. Frekuensi yang cocok untuk pengukuran pada daging ikan nila berformalin adalah frekuensi $1 \mathrm{kHz}-10 \mathrm{kHz}$.

\section{DAFTAR PUSTAKA}

1 Wu L, Ogawa Y, Tagawa A. Electrical Impedance Spectroscopy analysis of Eggplant Pulp and Effect of Drying and Freezing -Thawing Treatments on Its Impedance Charactersitic. Food Engineering. 2008;87:274-80.

2 Olarte O, Barbé K, Van Moer W, Van Ingelgem Y, Hubin A. Measurement and Characterization of Glucose in $\mathrm{NaCl}$ Aqueous Solutions by Electrochemical Impedance Spectroscopy. Biomedical Signal Processing and Control [Internet]. Elsevier Ltd; 2014 Nov [cited 2015 Feb 27];14:9-18. Available from: http://linkinghub.elsevier.com/retrieve/pii/S1746809414000949

3 Jaffrin MY, Morel H. Body Fluid Volumes Measurements by Impedance: A Review of Bioimpedance Spectroscopy (BIS) and Bioimpedance Analysis (BIA) Methods. Medical engineering \& physics [Internet]. 2008 Dec [cited 2015 Apr 28];30(10):1257-69. Available from: http://www.ncbi.nlm.nih.gov/pubmed/18676172

4 Purwanto RE, Sujatmiko A, Mesin JT, Malang PN, Hatta JS. Identifikasi Kerusakan Sel Melalui Pengamatan Perubahan Distribusi Impedansi Elektris. SENTIA. Malang: Politeknik Negeri Malang; 2009.

5 Fox CH, Johnson FB, Whiting J, Roller PP. Formaldehyde Fixation. Journal of Histochemistry and Cytochemistry. 1985;33(8):845-53.

6 Lorenzo A De, Andreoli A, Matthie J, Withers P, Haverkort EB, Binnekade JM, et al. Predicting Body Cell mass with Bioimpedance by Using Theoretical Methods: a Technological Review. Journal of Applied Physiol [Internet]. 1997;82:1542-58. Available from: http://jap.physiology.org/cgi/reprint/82/5/1542

7 Ivorra A. A . Bioimpedance monitoring for physicians : an overview 1. Medicina per a No Metges (Medicine for non physicians). Barcelona; 2002. p. 131-78.

8 Noor JA. Impedance Tomography. 2010.

9 Riyanto B, Maddu A, Supriyanto. Pendeteksian Tingkat Kesegaran Filet Ikan Nila Menggunakan Pengukuran Sifat Biolistrik. Jurnal Pengolahan Hasil Perikanan Indonesia. 2012;15. 